\title{
Multidisciplinary Investigations at Stalag Luft III Allied Prisoner-of-war Camp: The Site of the 1944 "Great Escape," Zagan, Western Poland
}

\author{
J.K. Pringle, ${ }^{1, *}$ P. Doyle, ${ }^{2}$ and L.E. Babits ${ }^{3}$ \\ ${ }^{1}$ School of Physical Sciences and Geography, Keele University, Keele, \\ Staffs ST5 5BG, U.K. \\ ${ }^{2}$ Department of Earth Sciences, University College London, Gower Street, \\ London WC1E 6BT, U.K. \\ ${ }^{3}$ Faculty of Arts \& Science, East Carolina University, Greenville, NC 27858, \\ USA
}

\begin{abstract}
Stalag Luft III, situated in Zagan, Poland (formerly eastern Germany), was the site of a World War II Allied aviator prisoner of war (POW) camp famous for repeat escape attempts-notably the mass escape of 76 POWs in March 1944, shown in the 1963 film "The Great Escape." The site has had little attention to date because it was within restricted military training grounds until 1992. This paper reports on attempts to locate the undiscovered "Dick" escape tunnel (the "Tom" and "Harry" tunnels from the same escape attempt were discovered and destroyed by camp authorities). Geological and geophysical surveys located hut 122, which contained the "Dick" entrance shaft. Subsequent archaeological investigations included surface artifact collection and inspection of the rubble-filled, tunnel entrance shaft. Excavations to a depth of $10 \mathrm{~m}$ through yellow glacio-fluvial sand resulted in the discovery of the refilled "Dick" tunnel with intact bed-board shoring and ventilation system. Our investigation provides valuable insights into POW escape efforts. (C) 2007 Wiley Periodicals, Inc.
\end{abstract}

\section{INTRODUCTION}

By December 1939, the German High Command separated prisoners-of-war (POWs) into their respective service arms and ranks. Among the many categories of POW camps; Kriegsgefangener Offizierlager (Oflags) contained mostly army officers; Kriegsgefangener Stammlager (Stalags) contained other military ranks; and Kriegsgefangener Marinenlager (Marlag) contained naval personnel. The German Air Force (Luftwaffe) ran their own POW camps (Kriegsgefangener Stammlager Luftwaffe) for captured Allied airmen. Escaping, or attempting to escape, from captivity was a feature of most POW camps (Evans, 1945; Rogers, 1946; Crawley, 1956). Although not all captives were engaged in this activity (McKenzie, 2004), in air force

*Corresponding author; E-mail: j.k.pringle@esci.ac.uk

Geoarchaeology: An International Journal, Vol. 22, No. 7, 729-746 (2007)

(C) 2007 Wiley Periodicals, Inc.

(WILEY

Published online in Wiley Interscience (www.interscience.wiley.com). DOI:10.1002/gea.20184 

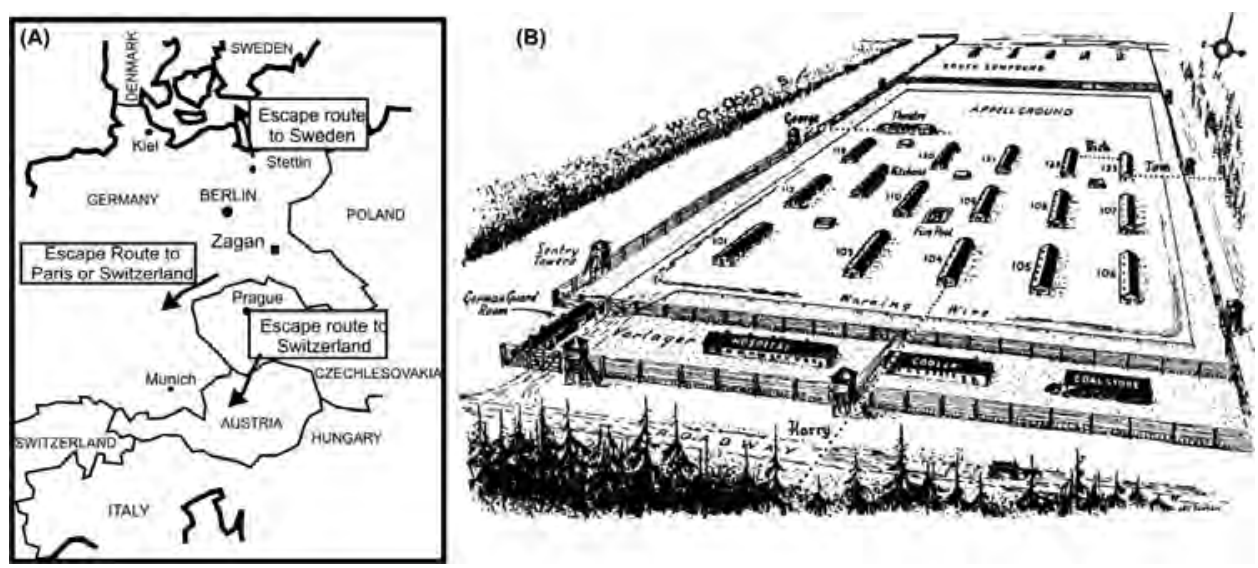

Figure 1. (A) WWII map showing the location of Stalag Luft III POW camp in Zagan. (B) Hand-drawn illustration of the camp's North Compound (from Brickhill, 1950). The target tunnel, "Dick," originates from hut 122 .

camps alone at least 60 escape tunnels were under construction between May 1942 and March 1943 (Crawley, 1956). Other methods of escape, including deception and climbing over or crawling under the wire fences, were also attempted.

The official response to Allied escape attempts varied through the war, with policy in both army and air force camps leaning toward concentration of escapers in specially constructed camps (Sonderlager) with greater security. Eventually, many recaptured Allied airforce POWs ended up at Stalag Luft III, a camp located as far from neutral and Allied forces countries as possible (Figure 1). Stalag Luft III was specifically designed to deter and detect potential escapers, and was constructed over time as a series of separate compounds (Flockhart, 1945; Durand, 1988). The camp was situated within a typical East European dense, coniferous forest, close to the main Berlin-Breslau (now Wroclaw) rail route, providing access to the camp-as well as a temptation for would-be escapers. As new compounds were required, additional forest clearance took place. Significant phases of camp expansion occurred as increasing numbers of POWs arrived following the expansion of the Allied strategic bombing campaign of Germany. Such site expansion allowed prisoners to make covert measurements, inspect site plans, and prepare escape equipment (Crawley, 1956).

The site of Stalag Luft III has a gentle slope and is well drained. The soil has a gray, organic-rich A-horizon above a reddish-yellow B-horizon. The C-horizon consists of yellow, unconsolidated glacio-fluvial sand that was easy to dig (Figure 2). Unfortunately, the color of the glacio-fluvial sand sharply contrasted with the gray A-horizon materials, and, therefore, could be easily detected by camp guards as evidence of any digging activities. This proved to be the case during unannounced inspections by guards. Although huts were elevated on brick piers to deter excavation of tunnels directly beneath the housing structures, this did not thwart the prisoners' efforts. 


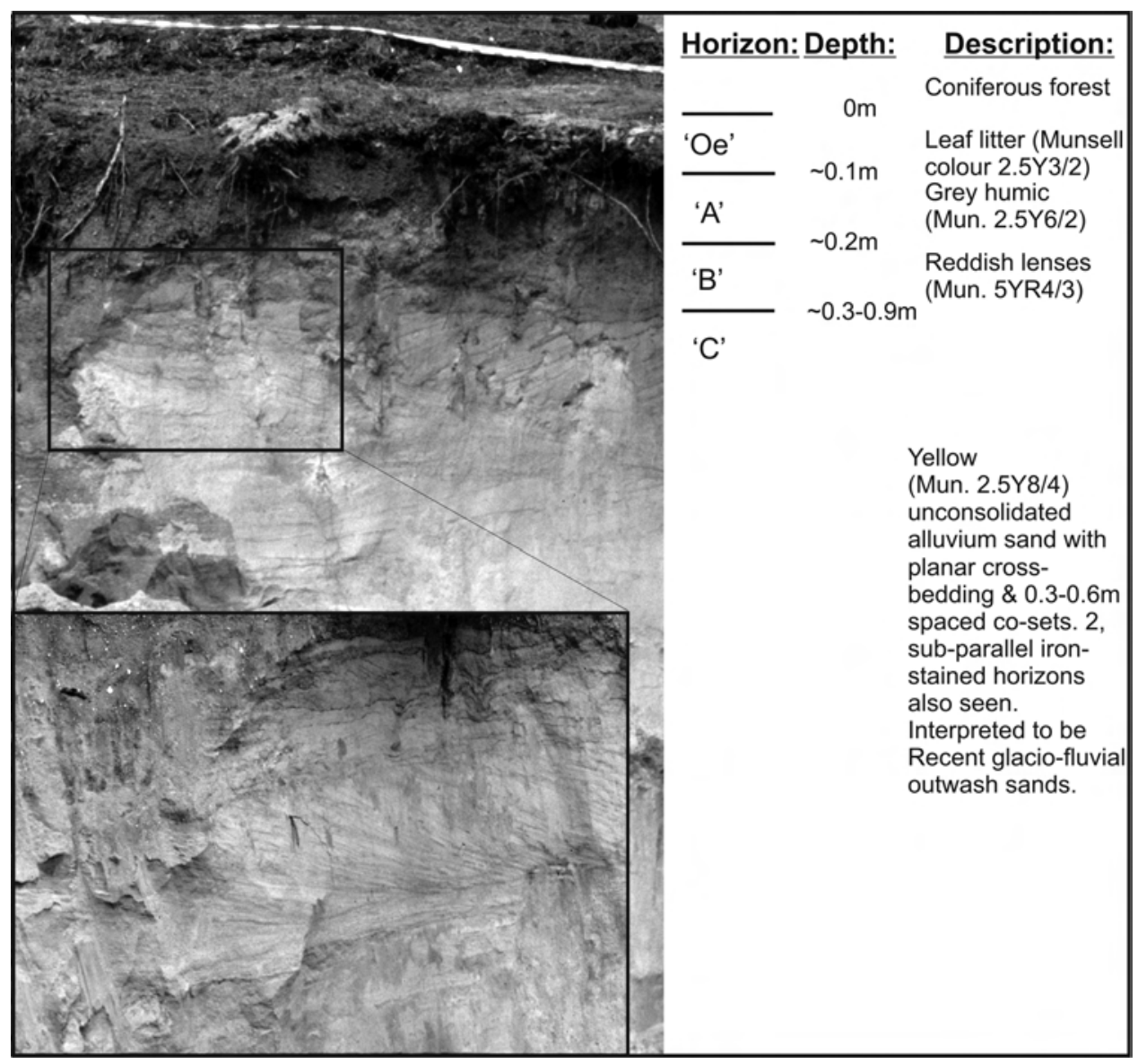

Figure 2. Photograph of undisturbed soil at the Stalag Luft III POW camp. Soil horizons are indicated and described to the right of the photograph. Note the sandy glacio-fluvial deposits (C-horizon) with planar cross-bedding (see inset).

Initial escape attempts from Stalag Luft III (from the original East Compound) were made with varying degrees of success and involved deception as well as both deep and shallow tunnels (Flockhart, 1945; Williams, 1949; Crawley, 1956). An escape committee, which was common in most POW camps, coordinated these efforts. Following the construction of the North Compound, into which many escapers were moved, a new escape committee, headed by "Big X" Squadron Leader Roger Bushell, was formed for this compound. The committee used previous experience to organize the simultaneous digging of three escape tunnels code-named "Tom," "Dick," and "Harry" in 1943-44 (Table I). Of these tunnels, "Tom" was discovered and destroyed by the camp guards in 1943 (Brickhill, 1950; James, 1983). Following this discovery, work on "Dick" was discontinued, with "Harry" being used for the "Great Escape" on the night of March 23-24, 1944, when 76 POWs actually exited the tunnel (see Brickhill, 
PRINGLE ET AL.

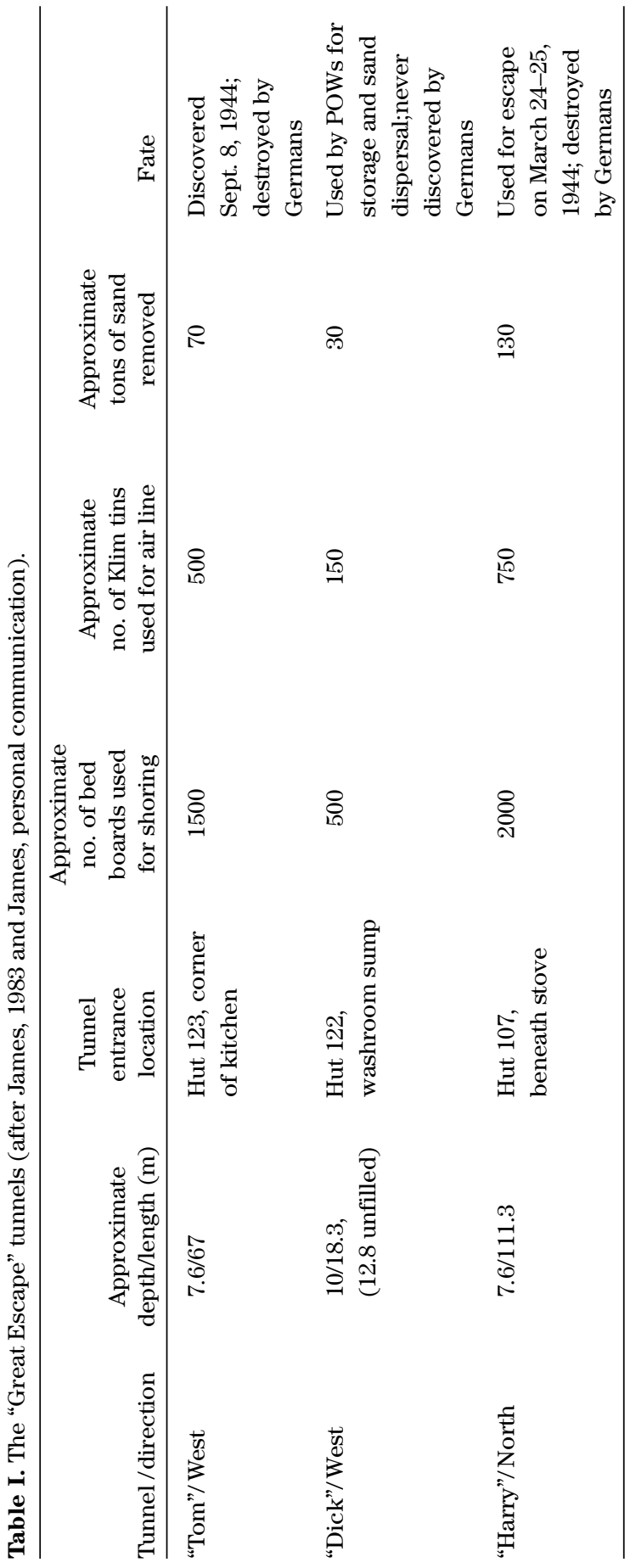


1950; Crawley, 1956; James, 1983; Durand, 1988). Following the escape, it is estimated that 5 million Germans were mobilized to recapture them. Of the 76 that escaped, 3 eventually reached Allied territory, but the remainder were recaptured, and 50 of them were executed by the Gestapo.

After the camp was evacuated in January 1945, Soviet troops utilized the site as a German POW holding camp (finds on-site confirm this). Since May 1945, the abandoned camp has been extensively looted, and none of the wooden portions of the huts remain. Stoves were broken down and removed, and there was a systematic removal of drainage systems that consisted of extensive, relatively narrow-gauge terracotta pipes. The original location of the pipes can be determined from the post-war trenches dug to remove them. As a result of all this activity, only the huts' piers and washroom floors survive. In addition, the entire camp location has returned to forest and is covered by young fir trees. Evidence of its post-war use includes slit trenches, fox holes, tank emplacements, woodland fire-breaks, and excavations of relic hunters (Figure 3).

The objective of the multidisciplinary investigations conducted in September 2003 was to locate tunnel "Dick," and an initial overview of this work has been published (Doyle et al., 2005). The purpose of this paper is to describe more thoroughly work carried out on-site. Investigations at Stalag Luft III began with an effort to locate the "Dick" tunnel and entrance shaft, followed by a combination of surveys, including geophysical techniques, then an archaeological excavation phase to uncover the

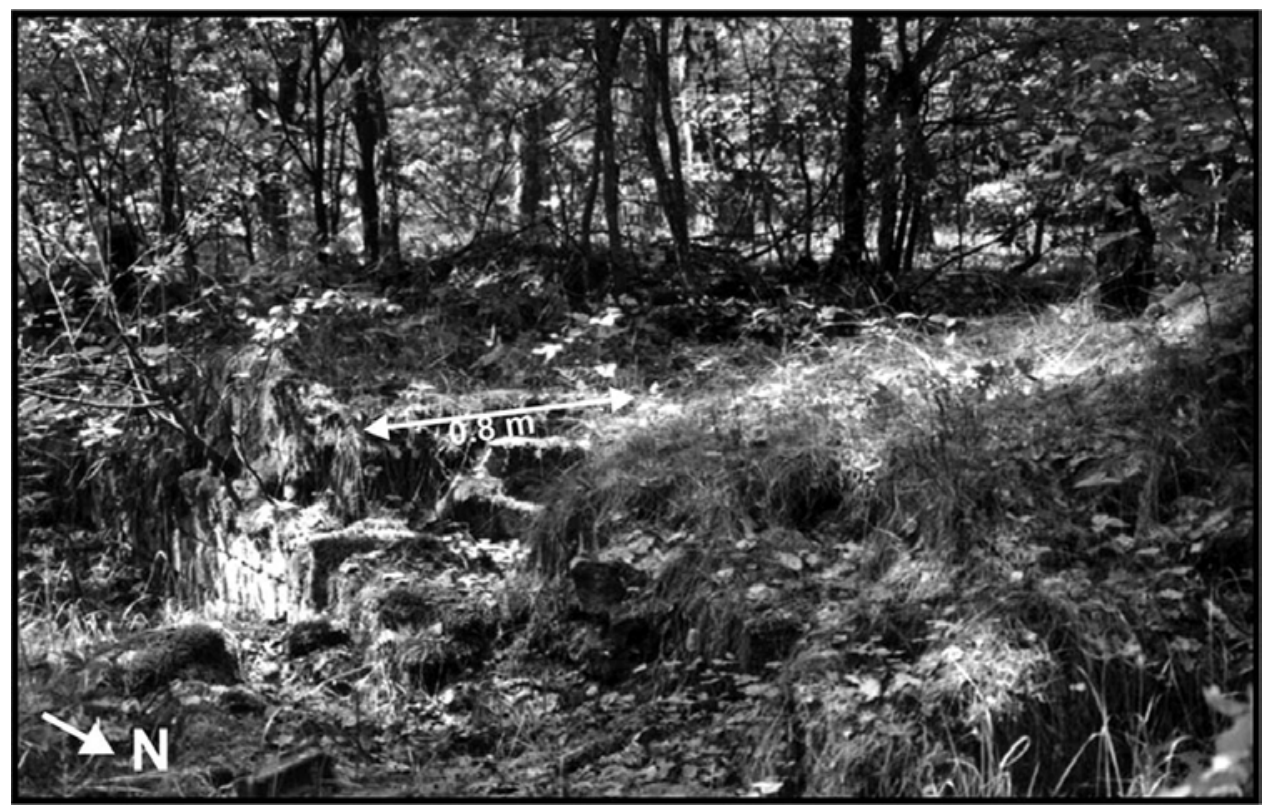

Figure 3. Photograph of the hut 123 locality. In addition to being overgrown with vegetation, the site has been disturbed by post-WWII military activities and relic hunters, making it difficult to reconstruct the original layout of the hut. 


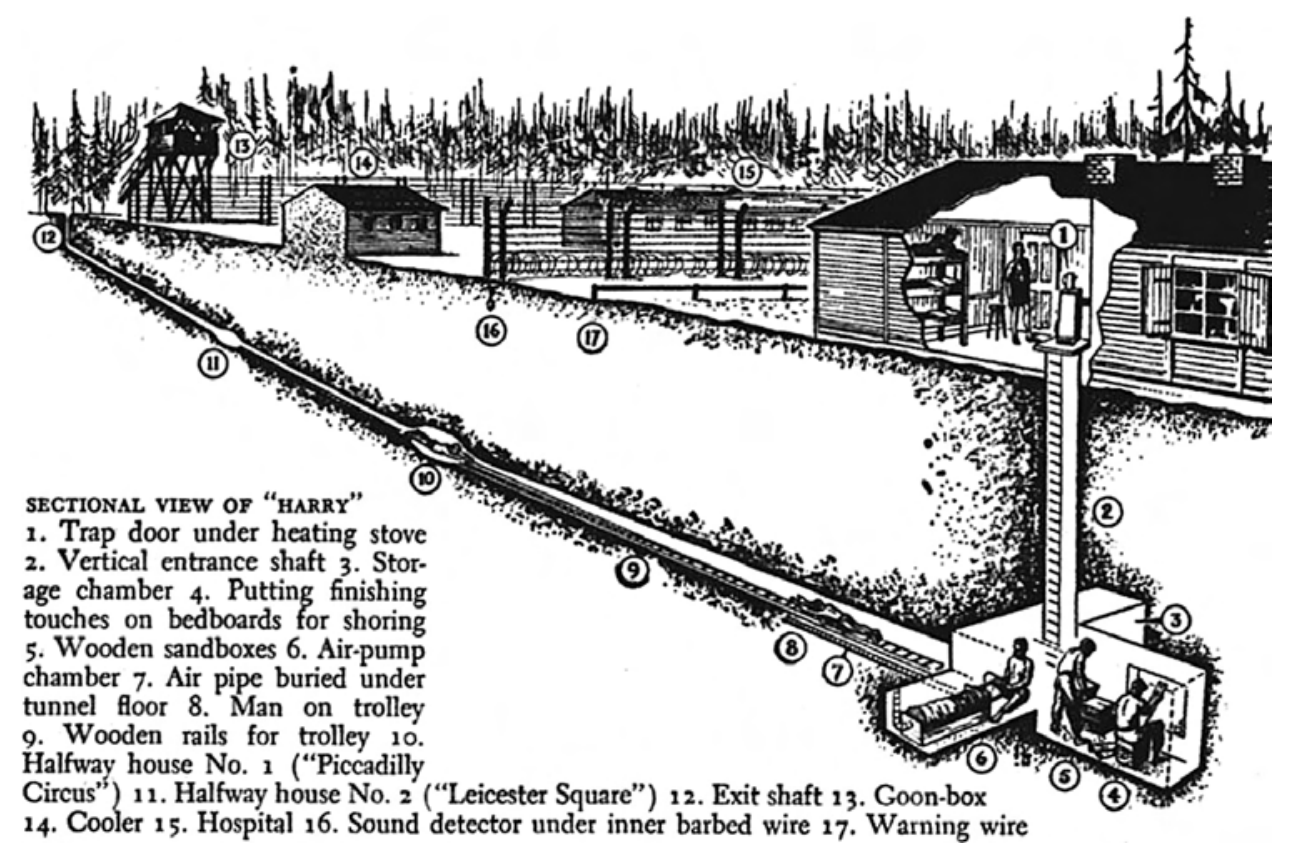

Figure 4. Illustration of "Harry" tunnel (from Brickhill, 1950).

tunnel and any subsurface storage chambers and associated artifacts (Figure 4). Three surviving POWs from Stalag Luft III-Major General David "Tokyo" Jones (retired), a "digger"; Lieutenant Colonel Charles Huppert (retired), a "manufacturer"; and Squadron Leader B.A. "Jimmy" James (retired), an "escaper"-were present onsite for guidance.

\section{INITIAL SITE INVESTIGATION}

\section{Site Surveys}

An initial site survey was undertaken in May 2003 to try to determine the location of hut 122, which, according to Brickhill (1950), contained the "Dick" tunnel entrance shaft. Because of reforestation and extensive looting of the site following World War II, the hut's location was very difficult to determine. Linear trenches left during the post-war removal of drainage pipes were useful, however, as they could be traced through the forest.

Hut locations on 1:10,000 site maps (Soviet and Polish) were found to be inaccurate; Allied 1944 aerial reconnaissance photographs were used instead to correlate present ground features with the camp structure (Figure 5A). Because of the dense woodland, it was not possible to undertake conventional theodolite surveying; measuring tapes and bearing information were used instead. The most important reference point located during the survey was an isolated, brick-lined fire pool (filled with water during occupation). This $20 \mathrm{~m}^{2}$ fire pool is visible in photographs taken during 

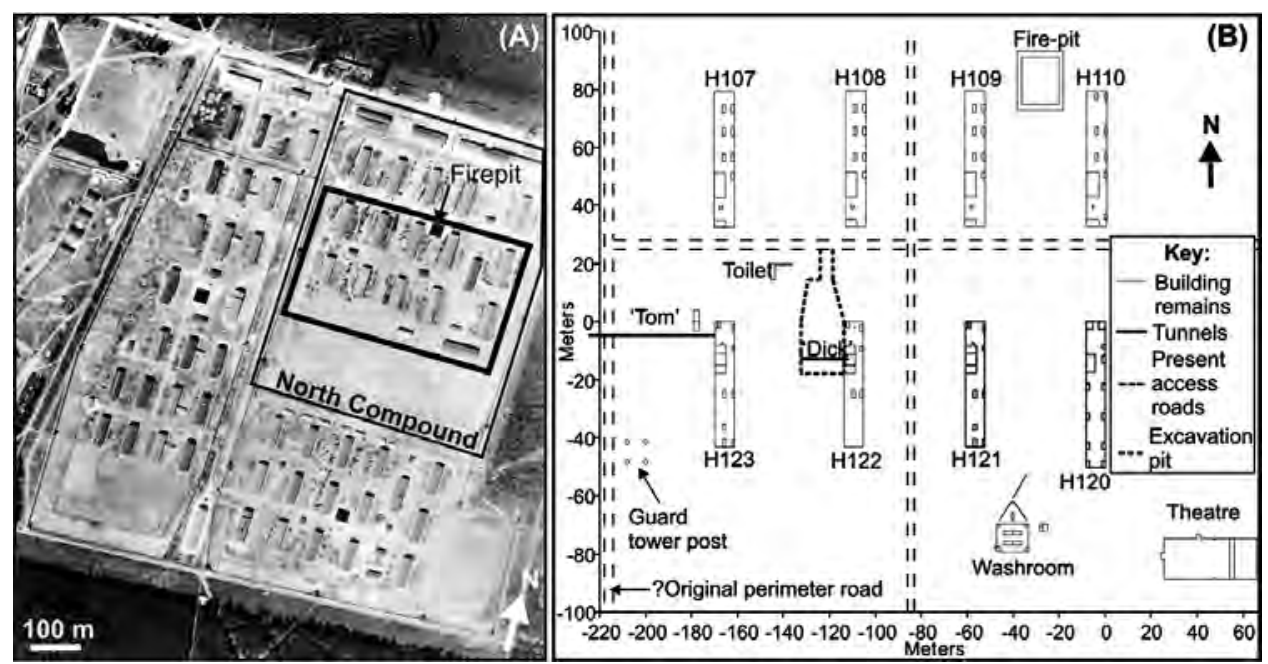

Figure 5. (A) World War II aerial reconnaissance photograph of Stalag Luft III POW camp. The North Compound is outlined on the photograph. (B) Plan view of the surveyed North Compound showing the locations of huts, roads, tunnels, and other features. The excavated area of the "Dick" escape tunnel also is shown.

the 1940s and thereby provided an accurate point from which the adjacent huts, including hut 122, could be located. Aborts (washrooms), the theater, former roads, and observation-post remains also were recorded. This was the first time the site had been surveyed since German engineers constructed the camp in 1944 (Figure 5B).

The foundations of huts 107 and 123 were surveyed in detail to obtain a hut foundation template, as they seemed to be the best preserved among the former structures (Figure 6). However, significant variation in the layout of the huts was observed. This had not been previously documented and was cause for concern because Brickhill (1950) noted that the "Dick" entrance shaft was beneath the washroom floor sump. There appear to be at least two construction styles: one for rows 101-106 and 107-112, which had internal washrooms at their southern end and iron stoves set on tile bases, and one for row 119-123, where internal washrooms were at the northern end and ceramic stoves were on concrete bases. This variation may indicate separate construction phases within the North Compound, although this has so far not been confirmed. Unexplained is the absence of an intervening hut row 113-118.

Each washroom had a flat, concrete floor with water-return rim, and a square brick-constructed, cement-rendered water-collection sump at its center. There were two terracotta pipes draining into the sump, and one draining to a water-collection point outside the hut perimeter. The fourth wall of the sump was featureless. The sump in hut 123 was well preserved and carefully surveyed. Subsequent archaeological excavations focused on this sump. The presumed sump area in hut 122 was poorly preserved, probably due to looters removing the drainage system, but a possible "crownhole" was recorded in the center to eastern half of the washroom. The sump location recorded in hut 123 was compared to the location of the crownhole 
PRINGLE ET AL.

(a) $\mathrm{H} 107$

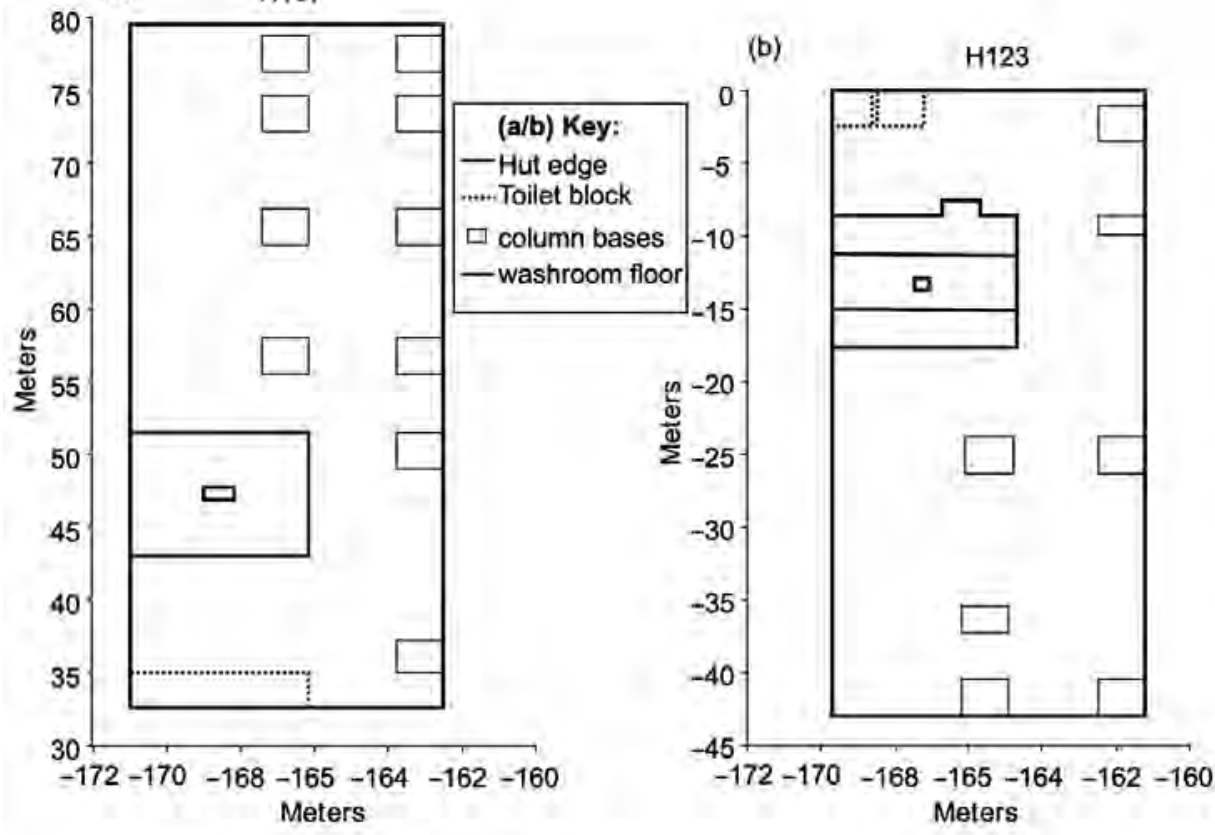

(c) SE Oubliette
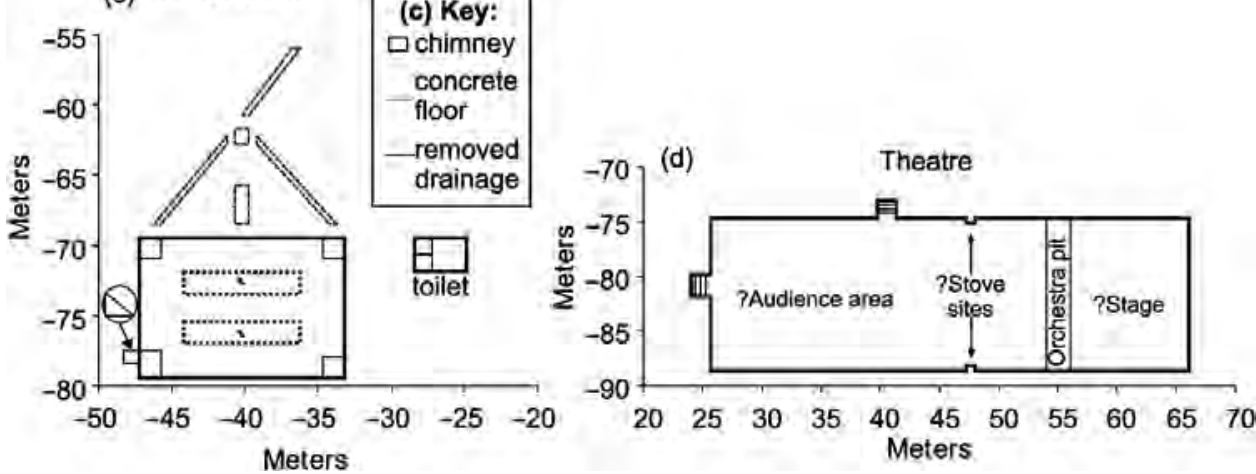

Figure 6. Surveyed areas of (a) hut 107, (b) hut 123, (c) an oubliette located at the southern end of the North Compound, and (d) the theater.

in hut 122. However, a geophysical survey was needed in order to provide targets for excavation.

\section{GEOPHYSICAL SURVEYS}

\section{Magnetometry}

Noninvasive geophysical investigations are commonly used to characterize or detect near-surface artifacts and cultural features. Despite limited access to metallic 
objects by the POWs (Brickhill, 1950), it was hoped that there might be enough metal in the entrance shaft, storage chamber, or tunnel to be detected. The magnetic method is probably the land-based geophysical tool most frequently used by archaeologists (e.g., Abbas et al., 2005; Abdallatif et al., 2005). In our study, proton precession magnetometer equipment was employed to acquire magnetic anomaly data. This equipment can be used to rapidly measure the total Earth's magnetic field at a specified sampling point. Variations in readings can be caused by different buried materials (e.g., metallic objects, pipes, etc.), but careful calibration with a known reference point is needed during sampling, as magnetic strength varies during the day (termed "drift"), with the strongest recordings occurring when the instrument is pointing north.

Magnetic data were collected along four lines orientated north-south, and one line oriented east-west over the supposed tunnel entrance beneath the sump (Figure 7). Results were corrected for drift and plotted. Although there was disappointingly little variation in readings observed around the presumed tunnel entrance shaft, a significant bipolar anomaly was observed $33 \mathrm{~m}$ south of the northern end of hut 122 (Figure 8A). Simple Mag2DC forward modeling of the magnetic anomaly showed a more than $0.5 \mathrm{~m}$ diameter metallic object at a depth of ca. $4 \mathrm{~m}$ (Figure $8 \mathrm{~B}$ ). This may be modern unexploded ordnance and was not investigated further for obvious safety reasons.

\section{Ground-Penetrating Radar}

Ground-penetrating radar (GPR) investigations of archaeological sites are now commonplace (e.g., Baker et al., 1997; Abbas et al., 2005), as near-surface electrical and magnetic property contrasts can be rapidly acquired and directly viewed during acquisition of high-resolution, two-dimensional profiles across a study site. (See Leckebusch [2003] for a useful overview of the GPR theory and archaeological applications.) It was hoped that angular supports used for tunnel shoring might still be in place, and therefore be imaged by the GPR survey. However, Brickhill (1950) noted that "Dick was full now to the base of the shaft" with the sand removed from "Tom," and the men were "also taking out the box frames and rails," something confirmed in historic accounts (Flockhart, 1945). If this were true, then it would be difficult to differentiate refilled tunnel sand from the undisturbed, sandy, glacio-fluvial deposits surrounding the tunnel. We were also concerned that significant subsurface disturbance resulting from military activities and relic hunters would compromise the GPR survey. Furthermore, it could be difficult to distinguish the target tunnel from other collapsed tunnels.

Following initial testing of the GPR PulseEkko ${ }^{\mathrm{TM}} 1000$ equipment using both 50 and $100 \mathrm{MHz}$ central frequency antennae, the $50 \mathrm{MHz}$ central frequency antennae were used to acquire two-dimensional, fixed-offset in-lines, orientated north-south, over the hut foundations, $3 \mathrm{~m}$ and $6.5 \mathrm{~m}$ west of hut 122 (Figure 6 ). The $0.25 \mathrm{~m}$ separated traces were acquired along each in-line with a 1000v transmitter, using a setup of 256 stacks and a $300 \mathrm{~ns}$ Time Window. A Common Midpoint (CMP) gather was also acquired; a subsequent velocity analysis of $0.15 \mathrm{~m} / \mathrm{ns}$ was used to convert profiles from two-way time (nanoseconds) to depth (meters). Standard post-acquisition GPR 
PRINGLE ET AL.

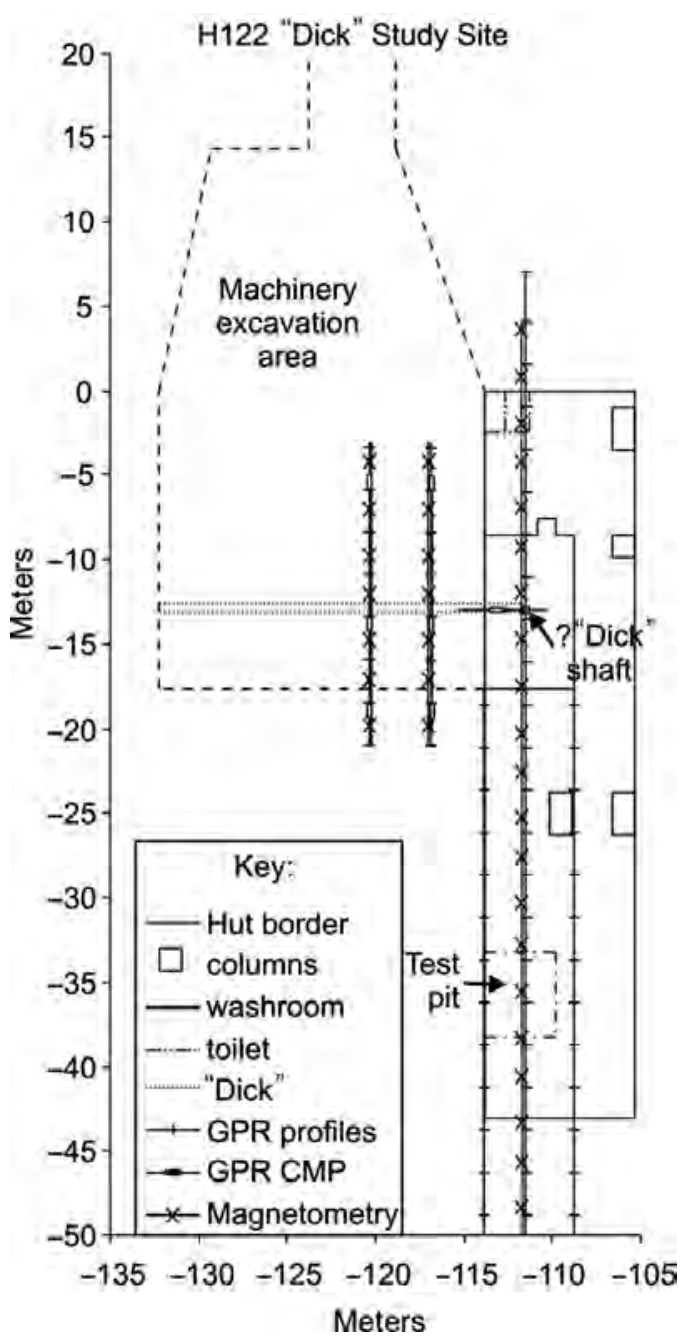

Figure 7. Plan view of the immediate area around the hut 122. Geophysical survey lines and excavation areas are shown.

processing (first break arrival corrections, AGC filter, and “dewow") were applied to optimize image quality. Static corrections were not needed, as in-lines had little topographic variation over the short survey lines.

One GPR profile in-line and interpretation is shown in Figure 9. Note that two sedimentary features were observed on the profile: particularly strong, coherent planar reflectors and inclined sets of related reflectors. Based on observations in a subsequent archaeological excavation unit, these reflectors were related to planar, iron-rich hard pans, approximately $25 \mathrm{~cm}$ thick, and inclined, glacio-fluvial cosets spaced approximately $4 \mathrm{~m}$ apart, respectively. Also, a linear disturbed area was detected with the GPR. This area of disturbance corresponds to the approximate 


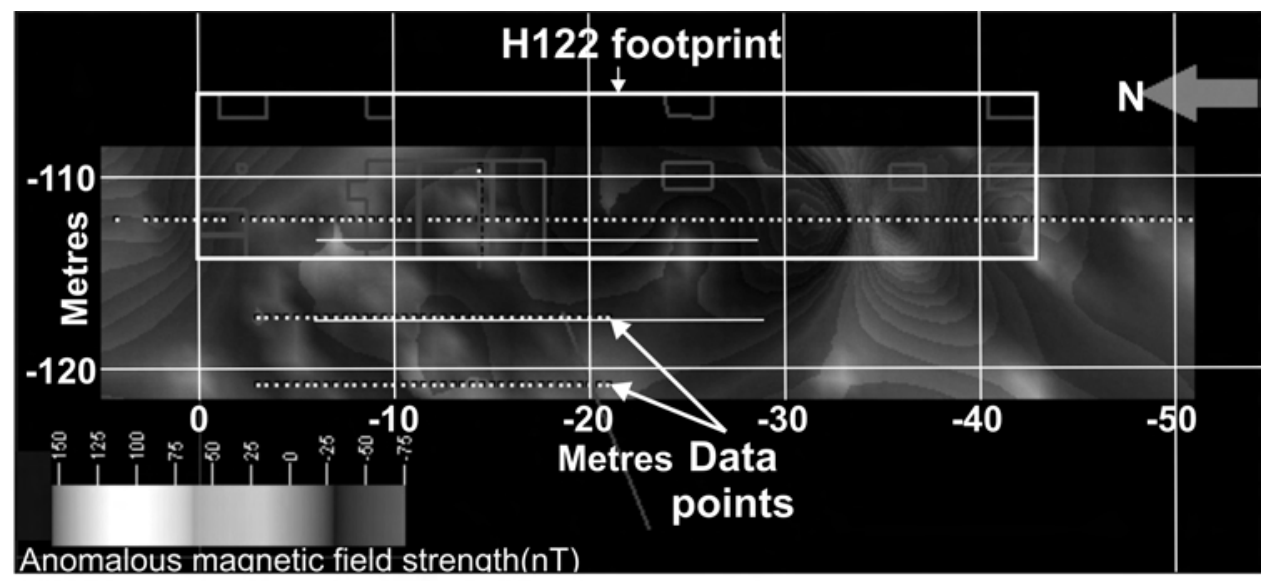

(B)

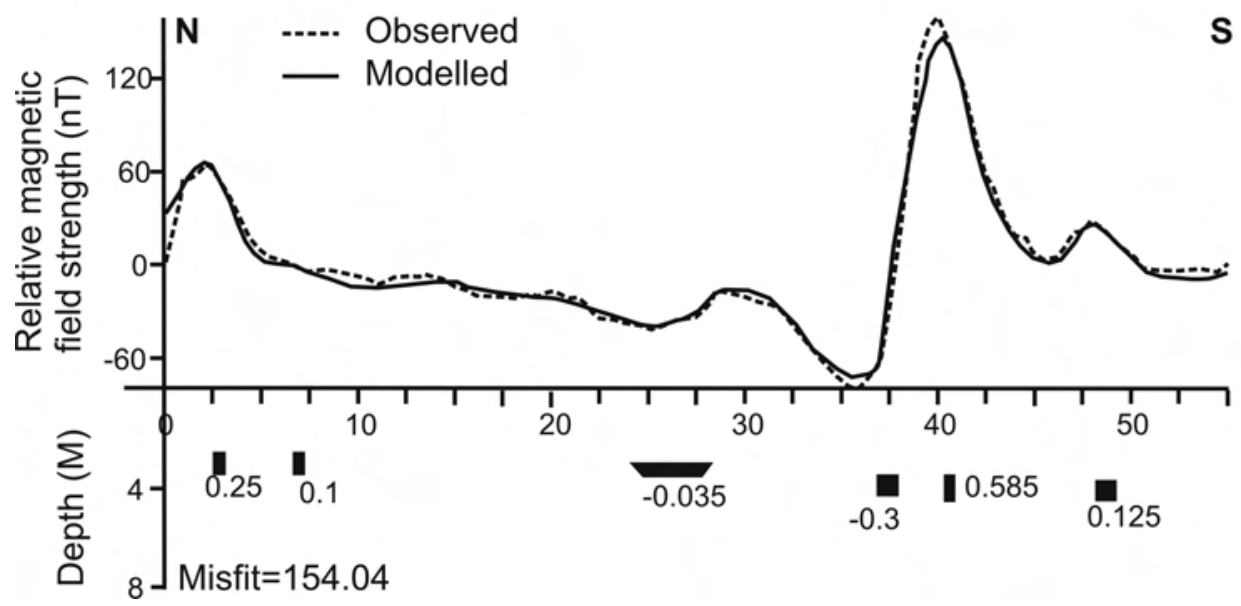

Figure 8. (A) Magnetic data collected for hut 122. The data have been calibrated to background magnetic strengths, then plotted and contoured. A strong variation was observed around $33 \mathrm{~m}$ south of the north end of the hut (seen by rapid change from negative to positive values). This anomaly has been forward modeled by Mag2DC software (B), with depth calculated to be $4 \mathrm{~m}$.

position of the "Dick" tunnel as determined by the preliminary survey, assuming the tunnel was aligned due west from the entrance shaft. A positive amplitude anomaly was also observed at the correct depth for the tunnel. Concave reflection events indicate buried object positions beneath the high points.

\section{ARCHAEOLOGICAL INVESTIGATIONS}

Archaeological excavations were conducted over a week in September 2003 and first focused on excavations of hut 122 . After a $1 \mathrm{~m} \times 1 \mathrm{~m}$ excavation grid covering $42 \mathrm{~m} \times 10 \mathrm{~m}$ was established, standard excavation procedures were employed to 
PRINGLE ET AL.

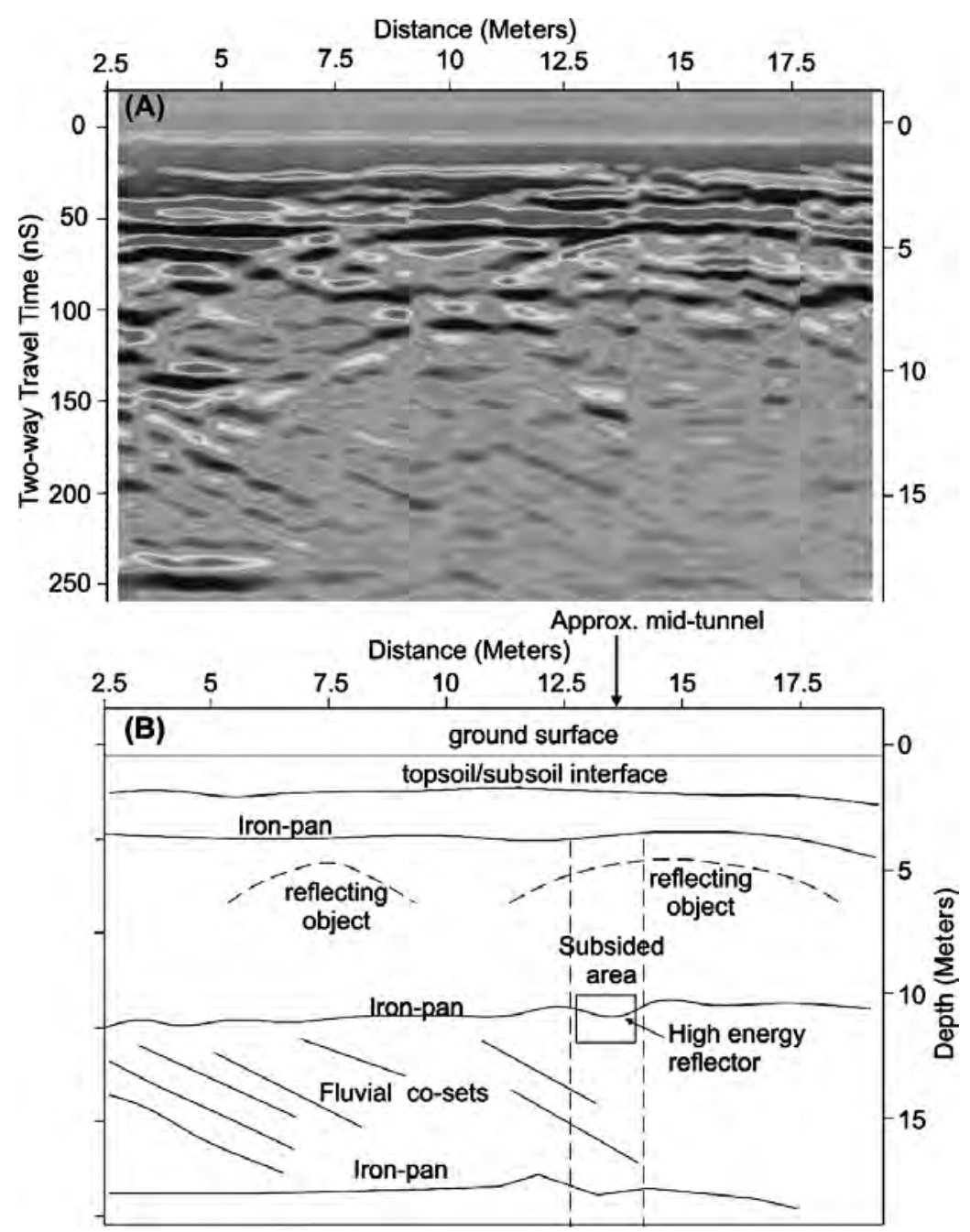

Figure 9. (A) GPR $50 \mathrm{MHz}$ frequency profile with $0.25 \mathrm{~m}$ trace spacing, and (B) interpretation from in-line 2, located $6.5 \mathrm{~m}$ west of hut 122 . This corresponds with the suspected location of the "Dick" tunnel.

expose, record, and recover artifacts in $10 \mathrm{~cm}$ levels. Sediment removed from excavation units was dry-screened through a 1/4-inch mesh. Virtually all artifacts were recovered from contexts disturbed by relic hunters.

A $5 \mathrm{~m} \times 7 \mathrm{~m}$ area of heavy but shallow disturbance was investigated midway along the long axis of hut 122 (marked as "test pit" in Figure 7). Despite the disturbance, it was possible to identify discrete artifact levels and recover materials more or less in situ from within the disturbed area. Among the recovered items was a potential "escape kit" within the remnants of a wire-bound attaché case. The kit contained a civilian-style coat, some buttons, a skein of thread, a blue glass marble, a checker piece, a toothbrush and case, a mess tin pan, and fragments of a German language book (Figure 10A-C). An artist's watercolor paint set and brush were also 

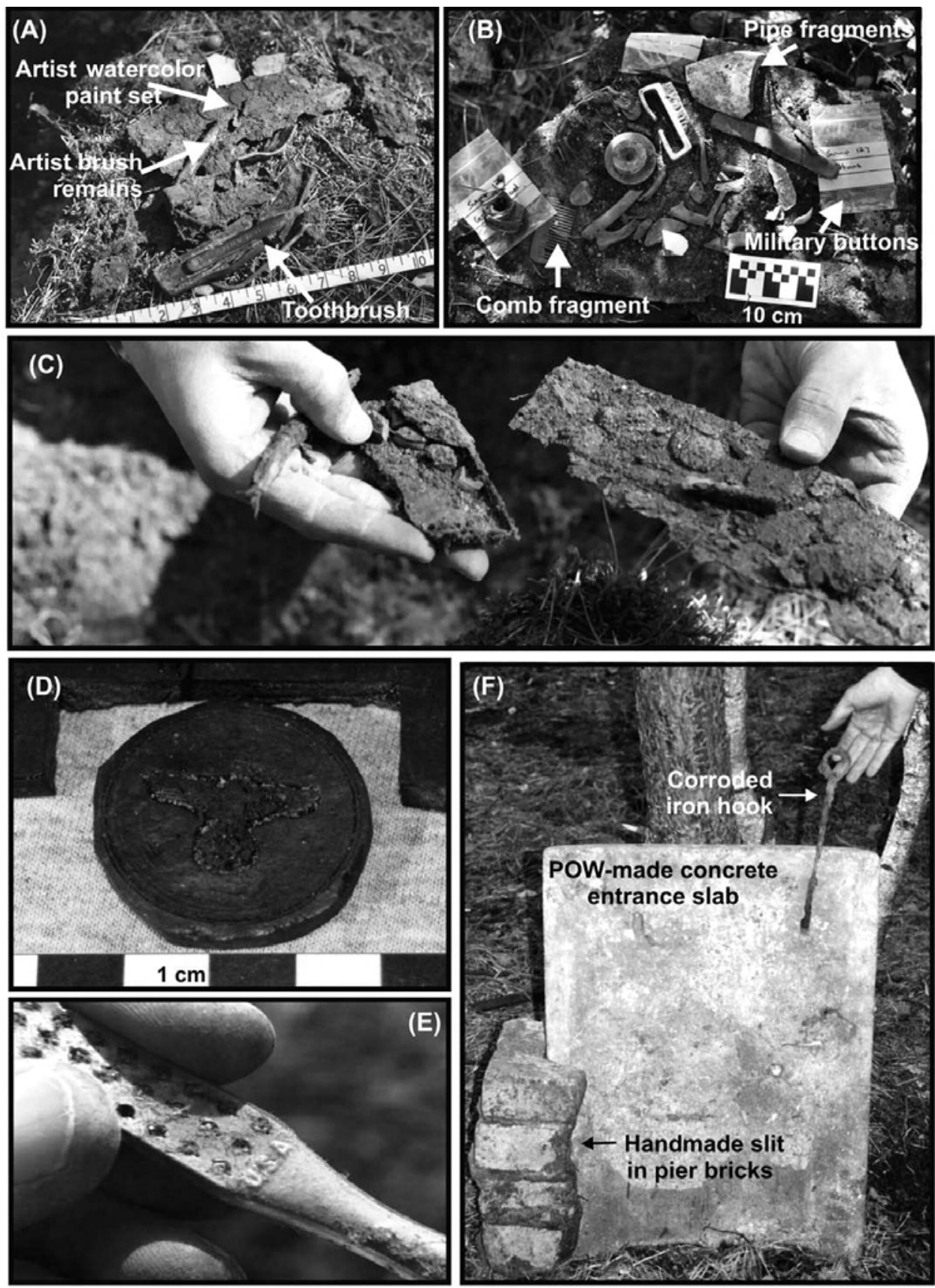

Figure 10. (A) Toothbrush and case found in the "escape kit," and an artist watercolor paint set and brush found beside the escape kit. (B) Other items in the kit included a comb fragment, pipe fragments, and military buttons. (C) Close-up photograph of the watercolor paint set. Artifacts recovered from sump included (D) Wehrmacht Pass stamp carved into POW rubber boot heel, (E) American toothbrush, and (F) POW-manufactured entrance slab and associated material. 
PRINGLE ET AL.

recovered with this case. The case probably was lodged beneath the hut for later retrieval. When the sump to hut 123 was investigated, it was found to contain artifacts consistent with its use, including underwear buttons, small animal bones, a hairbrush, and a nailbrush (Figure 10D-F).

Archaeological investigations also focused on the presumed tunnel entrance shaft (marked in Figure 7) that was accessed via one side of the hut 122 washroom sump. Troweled hand excavation of the $1 \mathrm{~m} \times 1 \mathrm{~m}$ area of disturbed soil, brick, concrete, and pipe debris was undertaken. A $47.5 \mathrm{~cm} \times 65.5 \mathrm{~cm} \times 4 \mathrm{~cm}$ thick concrete slab with two notches on one face was found within the sump fill. The slab's edge above the notches was slightly abraded (Figure 10F). A corroded, $26 \mathrm{~cm}$ long iron hook also was found, the hook end perfectly fitting the notches and edge of the concrete slab. This hook probably was used to pull up the slab door to allow shaft access. Between the sump floor and a north-south-orientated concrete "sill" was a groove $4 \mathrm{~cm}$ wide and sill slits on two narrow red bricks. According to tunnel veteran General Jones, tunnel workers slipped over the sill when entering the shaft beside the sump. Gray clay (possibly mixed with issue soap) was also found within the sill and probably was used to seal off the slab to prevent sump leakage into the shaft.

Excavations below the floor of the sump and the debris layer exposed an area of mottled soil that is $56 \times 64 \mathrm{~cm}$ in plan view. This mass of soil probably represents backfill, but is too narrow for the complete shaft. Due to safety concerns over the $10 \mathrm{~m}$ deep vertical shaft, further excavations were discontinued at this locality. The following artifacts were recovered during excavation of the entrance shaft and backfilled tunnel: a lamp made from a Red Cross parcel cheese tin (identified by Squadron Leader James and Lieutenant Colonel Huppert) and an associated candle that was used for lighting when the camp electricity was cut during air raids; some electrical flex cable and a porcelain electrical light fitting with opal glass fragments; and a rough-cut rubber disk from a boot heel, bearing a Wehrmacht eagle incised on one side with its head pointing to the right—consistent with its use as a stamp, as the usual direction is to the left (Figure 10D).

A final investigation phase involved tree removal, then machinery excavation west of hut 122 above the presumed tunnel location (see Figure 7 ). The $30 \mathrm{~m} \times 20 \mathrm{~m} \times 10 \mathrm{~m}$ excavation was designed to avoid disturbing in situ materials, as this area was known to contain POW gardens close to the huts and beyond the hut perimeter. Approximately $2000 \mathrm{~m}^{3}$ were excavated before being backfilled. Tunnel remains were discovered $10 \mathrm{~m}$ below the modern land surface (Figure 11A). Specifically, parallel wood stains were discovered on the walls of the tunnel. The stains were about $2.5 \mathrm{~cm}$ thick and $60 \mathrm{~cm}$ apart, corresponding to bed-board shoring sizes. These remnants of tunnel framing were consistent with historic accounts of the tunnel construction (Flockhart, 1945). In addition, a number of wooden frames were uncovered that extended above the wall shoring. These were interpreted as frame remnants against which the bed boards were braced (Figure 11B). Also, a few horizontal $1.2 \mathrm{~m}$ long wood remnants and stains were found running parallel to the tunnel axis. The discovery of wooden boards was significant because, according to Brickhill (1950), the POWs removed most shoring before filling "Dick" with sand taken from "Tom." 

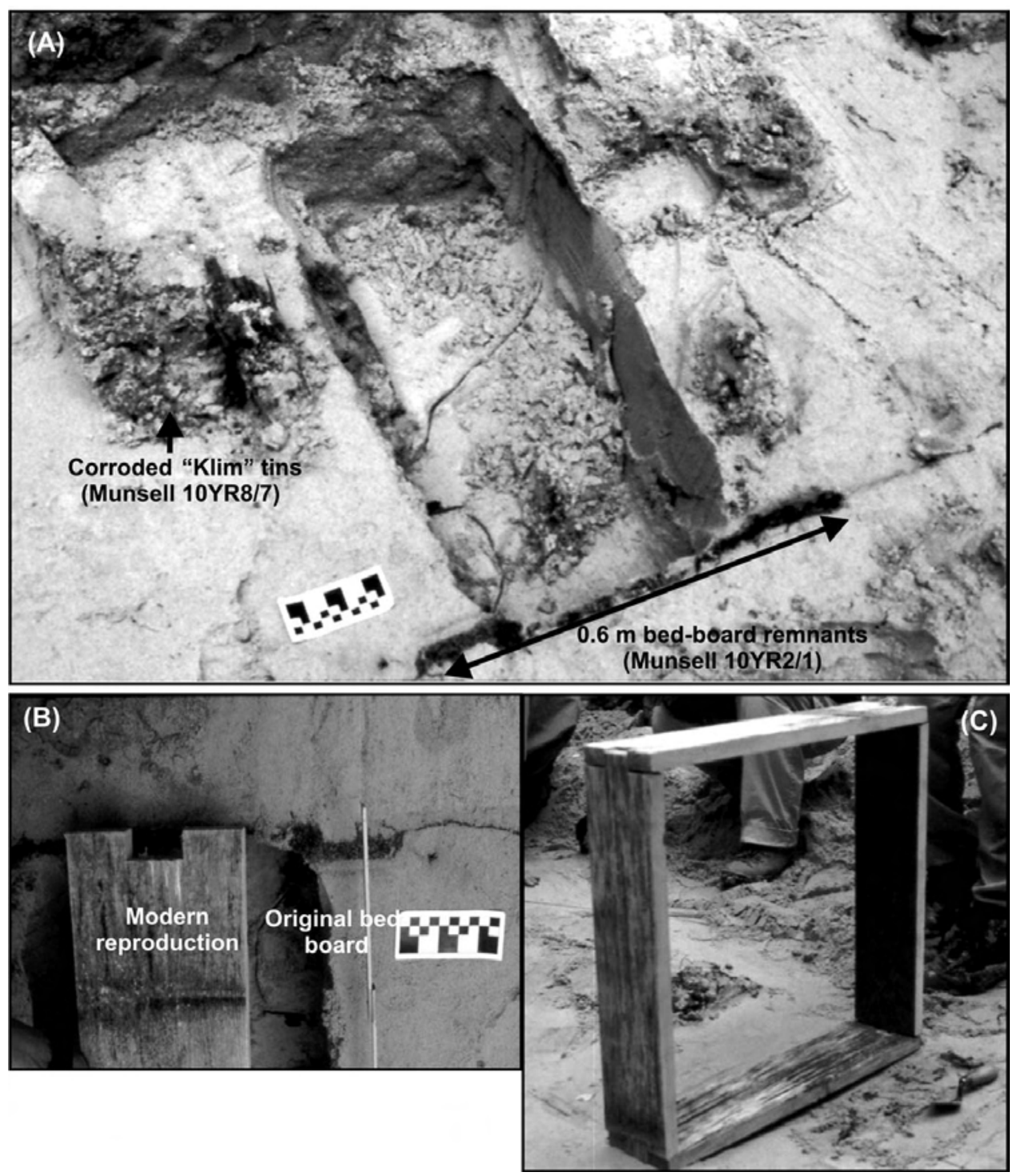

Figure 11. Photograph of (A) the bottom of "Dick" tunnel and the remains of the ventilation system; (B) an original and reproduced bed board; and (C) a reproduction of a bed-board frame used as shoring in the tunnel. 
PRINGLE ET AL.

At a point $30 \mathrm{~m}$ west of the entrance shaft, four $10 \mathrm{~cm}$ diameter "Klim" tin cans were found joined together beneath a bed board in the tunnel center (Figure 11A). These Red Cross dried-milk cans formed a tunnel ventilation system, running the length of the tunnel, from the diggers working at the sand face to a full-time worker pumping handmade bellows at the entrance shaft base to keep air circulating (Brickhill, 1950). Also, a small piece of cellophane that, according to Charles Huppert, may be from a cigarette packet (probably Chesterfield or Camel brand) was recovered from the tunnel floor. Crawley (1956) reported men smoked in halfway stations during tunneling.

Other artifacts recovered at Stalag Luft III were concentrated in isolated areas. These concentrations were located during the geophysical survey and are within the footprints of former huts. They may represent manufacturing and/or safe storage areas, but this is difficult to confirm.

\section{SUMMARY AND CONCLUSIONS}

Despite poor site preservation, dense vegetative cover, and considerable site disturbance, the multidisciplinary investigation of Stalag Luft III proved successful in locating a variety of features in this World War II POW camp, including the entrance shaft and tunnel ("Dick") used in the March 1944 "Great Escape." Initially, 1944 aerial reconnaissance photographs were compared with observations on the ground in order to locate camp structures, including hut 122, which harbored the entrance shaft to "Dick." This photo-supported surface survey was followed by a noninvasive magnetic and GPR survey of the camp. The geophysical survey had mixed success. Magnetometry was useful in detecting concentrations of ferrous-rich materials at shallow depths $(<5 \mathrm{~m})$, but failed to locate the refilled "Dick" escape tunnel. This failure is attributed to the paucity of ferrous-rich objects, the small magnetic susceptibility difference between the undisturbed glacio-fluvial deposits and the sand used to refill the tunnel, and the great depth $(10 \mathrm{~m})$ of the target. However, the GPR detected a linear disturbed area corresponding to the approximate position of the "Dick" tunnel, as determined by the initial surface survey.

Results of the geophysical survey allowed areas to be targeted for excavation, thereby increasing the efficiency of the archaeological investigation and reducing disturbance of in situ features and artifacts. The excavations revealed that the filled "Dick" tunnel was at a depth of $10 \mathrm{~m}$. Remnants of a wire-bound attaché case containing a possible "escape kit" were found within the tunnel's entrance shaft, and remains of wooden bed frames used for shoring were discovered in the former tunnel. Also, part of the tunnel ventilation system, formed by connected metal Klim tins, was found intact. Former POWs assisted with the interpretation of the archaeological record (Figure 12). Recovered artifacts were donated to the nearby Museum of Allied Prisoners of War and Martyrdom in Zagan.

\footnotetext{
${ }^{1}$ Klim was the name given to powdered milk rations issued by the International Red Cross to allied prisoners in Axis Forces Captivity during World War II. The name is a simple reversal of the word "milk."
} 


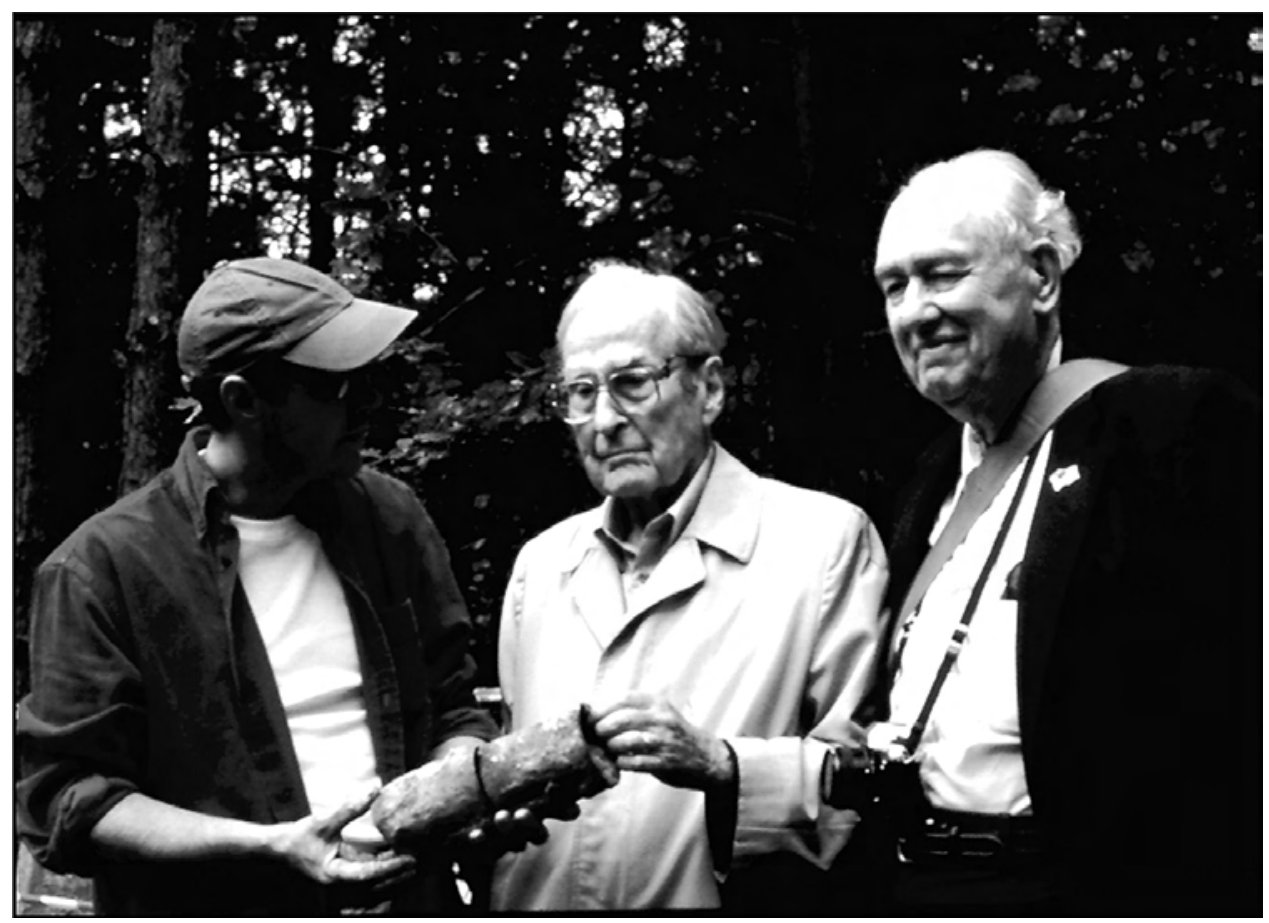

Figure 12. From left to right, Prof. Peter Doyle, Squadron Leader "Jimmy" James (RAF, retired), and Colonel Charles Huppert (USAAF, retired) with recovered joined Klim tins that formed part of the "Dick" tunnel ventilation system.

The site of Stalag Luft III is currently undeveloped and offers considerable potential for future investigations. It is estimated that over 100 tunnels were dug at this POW camp during World War II. Although the detection of so many tunnels may seem formidable, the methods used in our investigation for locating tunnel "Dick" proved cost-effective and relatively nondestructive. At least four other tunnels remain worthy of investigations: tunnel "Tom," destroyed in 1943; tunnel "Harry," the "Great Escape" tunnel destroyed or partially filled in 1944, after the breakout; tunnel "George," dug after the "Great Escape" as a potential mass escape tunnel in case of reprisals; and, in the East Compound, the "Wooden Horse" tunnel, which led to the successful escape of three prisoners in 1943 (Williams, 1949). Other POW camps in the region, including at least eight camps for non-airforce personnel, also merit study.

Our study demonstrated the value of multidisciplinary investigations, including geophysical surveys, at sites of conflict from World War II, and complements research at other localities such as Point du Hoc in Normandy, the site of the U.S. Ranger's attack in June 1944 (Everett et al., 2006). Surface survey and application of GPR and other geophysical techniques at Point du Hoc are increasing our understanding of the construction of World War II fixed fortifications (since destroyed), leading to better understanding of how these fortifications were constructed and how they stood up to the assault in 1944. It is important to note that opportunities to reconstruct sites 
PRINGLE ET AL.

such as these are enhanced by the abundant archive materials available for 20th century conflicts, as well as geophysical survey methods such as those applied at Stalag Luft III. Refined, these techniques may prove useful for investigating the extensive tunnels employed in World War I (e.g., Doyle et al., 2002).

Mark Radice, David Dugan, and Konrad Jankowski, producers of the documentary film that sponsored the excavation, are thanked for financial, logistical, and language support. Gabriel Moshenska and Daniel Phillips are acknowledged for archaeological assistance. Stalag Luft III veterans Major General David "Tokyo" Jones (retired), Lieutenant Colonel Charles Huppert (retired), and Squadron Leader B.A. "Jimmy" James (retired) are thanked for contemporary knowledge and on-site advice. Nigel Cassidy at Keele University is acknowledged for GPR interpretation assistance. Chris Leech is thanked for GPR hardware and software support, and Emma Preston is acknowledged for Schlumberger Petrel visualization software support. The authors wish to acknowledge Rolfe Mandel, Alston Thoms, and an anonymous reviewer whose efforts greatly improved the manuscript.

\section{REFERENCES}

Abbas, A.M., Abdallatif, T.F., Shaaban, F.A., Salem, A., \& Suh, M. (2005). Archaeological investigation of the eastern extensions of the Karnak Temple using ground-penetrating radar and magnetic tools. Geoarchaeology, 20, 537-554.

Abdallatif, T.F., Abd-All, E.M., Suh, M., Mohamad, R.M., \& El-Hemaly, I.A. (2005). Magnetic tracing at Abu Sir (Land of Forgotten Pyramids), northern Egypt. Geoarchaeology, 20, 483-503.

Baker, J.A., Anderson, N.L., \& Pilles, P.J. (1997). Ground penetrating radar investigations in support of archaeological investigations. Computers \& Geosciences, 23, 1093-1099.

Brickhill, P. (1950). The Great Escape (Vol. 1). London: Faber.

Crawley, A. (1956). Escape from Germany-A history of R.A.F. escapes during the war (Vol. 1). London: Collins.

Doyle, P., Barton, P., Rosenbaum, M., Vandewalle, J., \& Jacobs, K. (2002). Geoenvironmental implications of military mining in Flanders, Belgium, 1914-1918. Environmental Geology, 43, 57-71.

Doyle, P., Babits, L.E., \& Pringle, J.K. (2005). "For you the war is over": The archaeological record of Stalag Luft III escape attempts. Fields of Conflict III Annual Meeting, Nashville, TN.

Durand, A.A. (1988). Stalag Luft III. Baton Rouge, LA: Louisiana State University Press.

Evans, A.J. (1945). Escape and liberation, 1940-1945 (Vol. 1). London: Hodder \& Stoughton.

Everett, M.E., Pierce, C.J., Save, N., Warden, R.R., Dickson, D.B., Burt, R.A. \& Bradford, J.C. (2006) Geophysical investigation of the June 6, 1944 D-Day invasion site at Pointe du Hoc, Normandy, France. Near Surface Geophysics, 4, 289-304.

Flockhart, C.B. (1945). A typescript history of Stalag Luft III (Sagan), Air Force personnel reports, April 1942-January 1945. London: RAF Museum Archives, London RAF Museum.

James, B.A. (1983). Moonless night (Vol. 1). London: William Kimber.

Leckebusch, J. (2003). Ground-penetrating radar: A modern three-dimensional prospection method. Archaeological Prospection, 10, 213-240.

McKenzie, S.P. (2004). The Colditz myth. Cambridge, MA: Harvard University Press.

Rogers, D.J. (1946). An escape tunnel in Germany. The Mining Magazine, 75, 87-97.

Williams, E. (1949). The wooden horse. London: Collins.

Received August 22, 2005

Accepted for publication May 25, 2007 